\title{
EFFECTS OF LONG-TERM CONSERVATION TILLAGE ON SOIL NITROGEN CONTENT AND ORGANIC NITROGEN COMPONENTS IN A CHINESE MOLLISOL
}

\author{
HuANG, D. D. ${ }^{1,2 \#}-$ CHEN, X. W. $.^{2,3 \#}-$ CAO, G. J. ${ }^{1 *}-$ LIANG, A. Z. ${ }^{2,3}-$ JiA, S. X. ${ }^{2,3}-$ LIU, S. X. ${ }^{1}$ \\ ${ }^{1}$ College of Resource and Environment, Jilin Agricultural University \\ 130118 Changchun, China
}

${ }^{2}$ Key Laboratory of Mollisols Agroecology, Northeast Institute of Geography and Agroecology, Chinese Academy of Sciences, 130102 Changchun, China

${ }^{3}$ University of Chinese Academy of Sciences, 100049 Bejing, China

${ }^{\#}$ These authors contributed equally

*Corresponding author

e-mail:cgj72@126.com

(Received $31^{\text {st }}$ May 2018; accepted $1^{\text {st }}$ Aug 2018)

\begin{abstract}
The effect of different long-term (2001-2016) tillage practices on soil nitrogen forms in different soil layers were studied to provide a scientific basis for evaluating soil fertility and establishing rational fertilization measures. Soil contents of total nitrogen (TN), particulate organic nitrogen (PON), microbial biomass nitrogen (MBN), water soluble organic nitrogen (WSON), NO3-N content, NH4-N content ammonium nitrogen and organic acid nitrogen component contents were measured under notillage (NT) and mould plow (MP) treatments based on a long-term (16 year) conservation tillage experiment in Northeast China. The results showed that no-tillage increased soil total nitrogen, active nitrogen, inorganic nitrogen and organic nitrogen content, which varied with soil depth. Compared with MP, NT significantly $(\mathrm{p}<0.05)$ increased total nitrogen and active nitrogen content in the surface soil $(0-$ $30 \mathrm{~cm}$ ); TN, PON, MBN and WSON increased significantly ( $<0.05$ ) by $28.32 \%, 23.07 \%, 15.13 \%$ and $25.21 \%$ in $0-5 \mathrm{~cm}$ and by $10.17 \%, 19.4 \%, 15.97 \%$, and $31.33 \%$ in $5-10 \mathrm{~cm}$, respectively. For soil inorganic nitrogen, the content of ammonium nitrate at $0-5 \mathrm{~cm}$ and at $5-10 \mathrm{~cm}$ under NT was significantly ( $p<0.05$ ) higher than that of MP by $28.1 \%$ and $32.13 \%$, respectively, and the content of ammonium nitrogen in soil at $0-5 \mathrm{~cm}$ was significantly ( $\mathrm{p}<0.05$ ) higher, by $12.86 \%$, than that of MP. No-tillage significantly increased the content of total hydrolysable nitrogen, hydrolysable ammonia nitrogen, hydrolysable amino acid nitrogen and hydrolysable unidentified nitrogen in the $0-10 \mathrm{~cm}$ soil layer, but no significant effect was found on the content of hydrolysable amino sugar nitrogen. Soil nitrogen content was closely related to tillage practices. These results suggest that no-tillage was beneficial in augmenting soil nitrogen supply capacity by increasing soil total nitrogen, active nitrogen, inorganic nitrogen and organic nitrogen content.
\end{abstract}

Keywords: no-tillage, mould plow, soil nitrogen forms, straw returning, Northeast China

\section{Introduction}

Soil nitrogen $(\mathrm{N})$ is one of the necessary nutrients for plant growth and development, as well as a major nutrient limiting factor for crop yield (Gao et al., 2008; Karra et al., 2018; Lenssen et al., 2007; Sainju et al., 2009). Soil organic and inorganicnitrogen are the main forms of the nitrogen pool. Soil organic nitrogen content of approximately 70\%-90\% in surface soil could not only maintain soil nitrogen fertility (Xu et al., 2003), but also has an important function for soil nitrogen supply capacity (Ju et al., 2004). Soil inorganic nitrogen pools with ammonium and nitrate, is the most effective nitrogen pool type for crop absorption (Mkhabela et al., 2008). Approximately 50\% of the 
accumulated nitrogen in crops comes from soil, especially for the black soil of Northeast China where more than $70 \%$ of the plant's accumulated nitrogen comes from the soil (Fuzzi, 1996; Ballb et al., 1999). Therefore, soil $\mathrm{N}$ mineralization from organic to inorganic $\mathrm{N}$ is the key process for crop absorbing and utilizing $\mathrm{N}$.

Tillage practices have a great impact on soil $\mathrm{N}$ availability and nitrogen reserves. Intensive agricultural systems may deplete soil $\mathrm{N}$ pools by removal of the above ground portion of the plants, which may result in negative nutrient balance depleting soil fertility. Conservation tillage with returned straw could improve the soil aggregate structure, maintain soil moisture, reduce water runoff and evaporation, increase water infiltration, stabilize soil temperature changes, promote the reproduction of beneficial microorganisms and regulate nutrient metabolism, thus affecting the mineralization and transportation of soil $\mathrm{N}$ and plant absorption and utilization (Patra et al., 1993; Ram et al., 2003; Barajas-Guzmán et al., 2006). Therefore, it is critical to understand the dynamic and cycling of the soil $\mathrm{N}$ pools and their fractions under different agriculture management styles. Previous studies have shown that compared with traditional tillage, conservation tillage changed the soil microenvironment, thus affecting the mineralization and content of soil $\mathrm{N}$, such as no-tillage significantly increasing the total $\mathrm{N}$ content in the 0-5 cm soil layer (Lou et al., 2012; Varvel et al., 2011; Sainju et al., 2009; Dikgwatlhe et al., 2014). However, the soil total $\mathrm{N}$ pool changes slowly responding to the management practice changes because of its large size, inherent spatial variability, and small fraction available to plants. Therefore, more attempts have been made to labile fractions as plant-available N (Wander, 2004; Haynes, 2005), which is the most active component of soil organic N. Particulate organic nitrogen (PON), microbial nitrogen $(\mathrm{MBN})$ and water-soluble organic nitrogen (WEON) are the important active $\mathrm{N}$ pools, which play an essential role in the process of soil $\mathrm{N}$ cycle (Jones et al., 2004). No-tillage (NT) may temporarily increase $\mathrm{N}$ immobilization leading to reduced plant-available N, while long-term NT can also increase soil labile N pool to improve the availability of $\mathrm{N}$ to crops in the upper soil layers (Sun et al., 2015; Sainju et al., 2013).

The mollisol area in Northeast China is the main grain-producing area in the country. With the increment of reclamation years and predatory production, fertility degradation of the mollisol has become more and more prominent. It is now considered urgent to change the traditional farming methods and carry out conservation tillage as an effective means of preservation. Several previous studies have focused mainly on soil total nitrogen content change under conservation tillage, but focused less on soil active nitrogen, inorganic nitrogen and organic nitrogen components. Thus, in the current study, soil organic nitrogen contents between conservation tillage and conventional tillage were analyzed based on a long-term conservation experiment started in 2001. This involved analysis of soil nitrogen and organic nitrogen components under protective tillage and conventional tillage conditions, with a view to evaluating soil fertility, formulating reasonable fertilization measures and providing a scientific basis for sustainable development of agriculture.

\section{Material and methods}

\section{Study site}

The study was conducted on Dehui Experimental Station ( $\left.44^{\circ} 12^{\prime} \mathrm{N}, 125^{\circ} 33^{\prime} \mathrm{E}\right)$ of the Northeast Institute of Geography and Agroecology, Chinese Academy of Sciences, in 
Dehui County, Jilin Province, China. The climate is described as a temperate continental monsoon; based on data from the past 30 years, the annual mean air temperature is $4.4{ }^{\circ} \mathrm{C}$, and the annual mean precipitation is $520.3 \mathrm{~mm}$, with more than $70 \%$ of the rain occurring in June, July, and August. The winter (November-April) is long and cold. The soil is a clay loam (Typic Hapludoll) unusually covered with snow in winter. More details about the soil can be found in Table 1 (Chen et al., 2018). Conventional management practices were used on the land to grow a monoculture of maize for more than 20 years before the establishment of this tillage experiment.

\section{Experimental design}

The present study was conducted using monoculture maize in a long-term (20012016) tillage field experiment. The tillage and rotation treatment are as follows. The tillage treatments consisted of no-tillage (NT), mould plow (MP) tillage and ridge tillage (RT), with two crop rotations (continuous maize (Zea mays L.), and maizesoybean (Glycine max L.). All the treatments were arranged in a randomized complete block design with four replicates at the whole plot level, and each plot was $5.2 \mathrm{~m} \times$ $20 \mathrm{~m}$. The NT treatment had no soil disturbance except for planting, usually in early May. The RT treatment included ridging in June and less than one-third row width smashing of maize stalks/roots in fall. The MP treatment included one approximately $15 \mathrm{~cm}$ in depth moldboard plowing after maize harvest, generally in early October, and one 7.5 to $10 \mathrm{~cm}$ in depth disking during the spring, as well as field cultivation (ridging in June). Herbicides were applied before and after seeding for all the tillage treatments to control weeds. Starter fertilizer $\left(100 \mathrm{~kg} \cdot \mathrm{ha}^{-1} \mathrm{~N}, 45.5 \mathrm{~kg} \cdot \mathrm{ha}^{-1} \mathrm{P}\right.$ and $\left.78 \mathrm{~kg} \cdot \mathrm{ha}^{-1} \mathrm{~K}\right)$ and an additional $50 \mathrm{~kg} \cdot \mathrm{ha}^{-1} \mathrm{~N}$ at the $\mathrm{V}-6$ stage were applied for maize. Starter fertilizers $\left(40 \mathrm{~kg} \cdot \mathrm{ha}^{-1} \mathrm{~N}, 60 \mathrm{~kg} \cdot \mathrm{ha}^{-1} \mathrm{P}\right.$ and $80 \mathrm{~kg} \cdot \mathrm{ha}^{-1} \mathrm{~K}$ ) were applied concurrently at the time of planting for soybean. The crop residues were returned onto the soil surface after harvest under NT and RT treatments with the exception of the plots under MP.

Table 1. Selected soil physical and chemical properties in 2001 prior to the tillage experiment (Chen et al., 2018)

\begin{tabular}{c|c|c|c|c|c|c|c}
\hline $\begin{array}{c}\text { Depth } \\
(\mathbf{c m})\end{array}$ & $\mathbf{p H}$ & $\begin{array}{c}\text { Clay (\%) } \\
(<\mathbf{2} \boldsymbol{\mu m})\end{array}$ & $\begin{array}{c}\text { Silt }(\boldsymbol{\%}) \\
(\mathbf{2 - 2 0} \boldsymbol{\mu m})\end{array}$ & $\begin{array}{c}\text { Sand }(\boldsymbol{\%}) \\
(\mathbf{2 0 - 2 0 0} \boldsymbol{\mu m})\end{array}$ & $\begin{array}{c}\text { Bulk density } \\
\left(\mathbf{g} / \mathbf{c m}^{\mathbf{3}}\right)\end{array}$ & $\begin{array}{c}\text { Soil organic } \\
\mathbf{c a r b o n} \\
(\mathbf{g} / \mathbf{k g})\end{array}$ & $\begin{array}{c}\text { Total soil } \\
\text { nitrogen } \\
(\mathbf{g} / \mathbf{k g})\end{array}$ \\
\hline $0-5$ & 6.48 & 36.03 & 24.00 & 39.97 & 1.24 & 16.48 & 1.42 \\
$5-10$ & 6.45 & 35.83 & 23.78 & 40.39 & 1.38 & 16.29 & 1.39 \\
$10-20$ & 6.51 & 35.68 & 24.35 & 39.98 & 1.36 & 16.08 & 1.37 \\
$20-30$ & 7.03 & 36.56 & 25.00 & 38.72 & 1.38 & 14.22 & 1.16 \\
\hline
\end{tabular}

\section{Soil sampling and measurements}

Soil samples (7 replicates per plot) were collected at depths of $0-5 \mathrm{~cm}, 5-10 \mathrm{~cm}, 10$ $20 \mathrm{~cm}$ and 20-30 $\mathrm{cm}$ with S-type sampling on 23 April, 2017. The collected samples were divided into two parts, one was stored at $4{ }^{\circ} \mathrm{C}$ as a fresh sample for determination of microbial biomass nitrogen (MBN) and water-soluble organic nitrogen (WSON), and the other was air-dried for soil total nitrogen (TN), organic nitrogen components, etc. Soil total nitrogen was determined by an elemental analyzer (Flash EA1112, Thermo Finnigan, Italy). Particle organic nitrogen (PON) was extracted first and then analyzed 
by elemental analysis (Cambardella et al., 1992). Soil water-soluble organic nitrogen was determined by the TOC-VCPH automatic analyzer (Model TOC-VCPH, Shimadzu, Tokyo, Japan) (Gigliotti et al., 2002). Soil microbial nitrogen (MBN) was determined by a modified CHCL3 fumigation-extraction method (Vance et al., 1987), and the extractions were analyzed by the automatic TOC-VCPH analyzer. Soil organic nitrogen components were determined according to Bremner's method (Bremner, 1965). Soil inorganic nitrogen was determined by a fully automatic continuous flow analyzer (SKALAR SAN ++ , The Netherlands).

\section{Data analysis}

Statistical analyses were carried out using SPSS (Version 11.5, SPSS Inc., Chicago, IL, USA). Treatment means were compared using the least significant difference (LSD) and a significance level of $\mathrm{P}<0.05$.

\section{Results}

\section{Total nitrogen content}

Compared with MP, NT significantly $(\mathrm{p}<0.05)$ increased the total nitrogen content by $28.32 \%$ and $10.17 \%$, in the $0-5 \mathrm{~cm}$ and $5-10 \mathrm{~cm}$ soil depth intervals, respectively (Fig. 1). While the total nitrogen content of the $10-20 \mathrm{~cm}$ and $20-30 \mathrm{~cm}$ layers under NT treatment was slightly lower than that of MP, the difference was not significant. Under both NT and MP, soil total N decreased with increased soil depth.
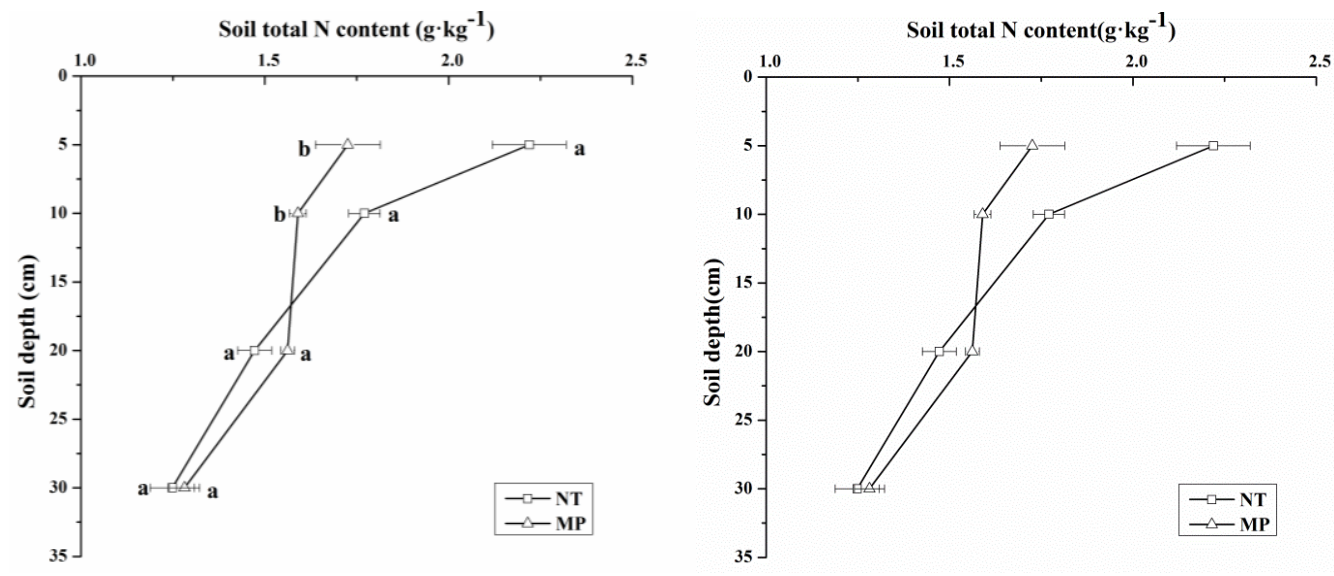

Figure 1. Soil total nitrogen at different soil depths under different tillage practices $(P<0.05)$. (NT: no tillage; MP: mould plow. Different letter indicates significant difference of soil total $N$ content between different tillage practices at the same depth)

\section{Active nitrogen}

NT significantly $(\mathrm{p}<0.05)$ increased soil active nitrogen in the $0-5 \mathrm{~cm}$ and $5-10 \mathrm{~cm}$ soil layers more than MP (Fig. 2). Particulate organic nitrogen increased by $23.07 \%$ and $19.4 \%$, microbial biomass $\mathrm{N}$ increased by $15.13 \%$ and $15.97 \%$, and soil soluble organic nitrogen increased by $25.21 \%$ and $31.33 \%$ in the $0-5 \mathrm{~cm}$ and $5-10 \mathrm{~cm}$ soil layers, respectively (Fig. 2). No significant differences were found between NT and MP for 
PON, MBN, and WSON in the 10-30 $\mathrm{cm}$ soil layer. With the increment of soil depth, PON, MBN, and WSON showed a decreasing trend.
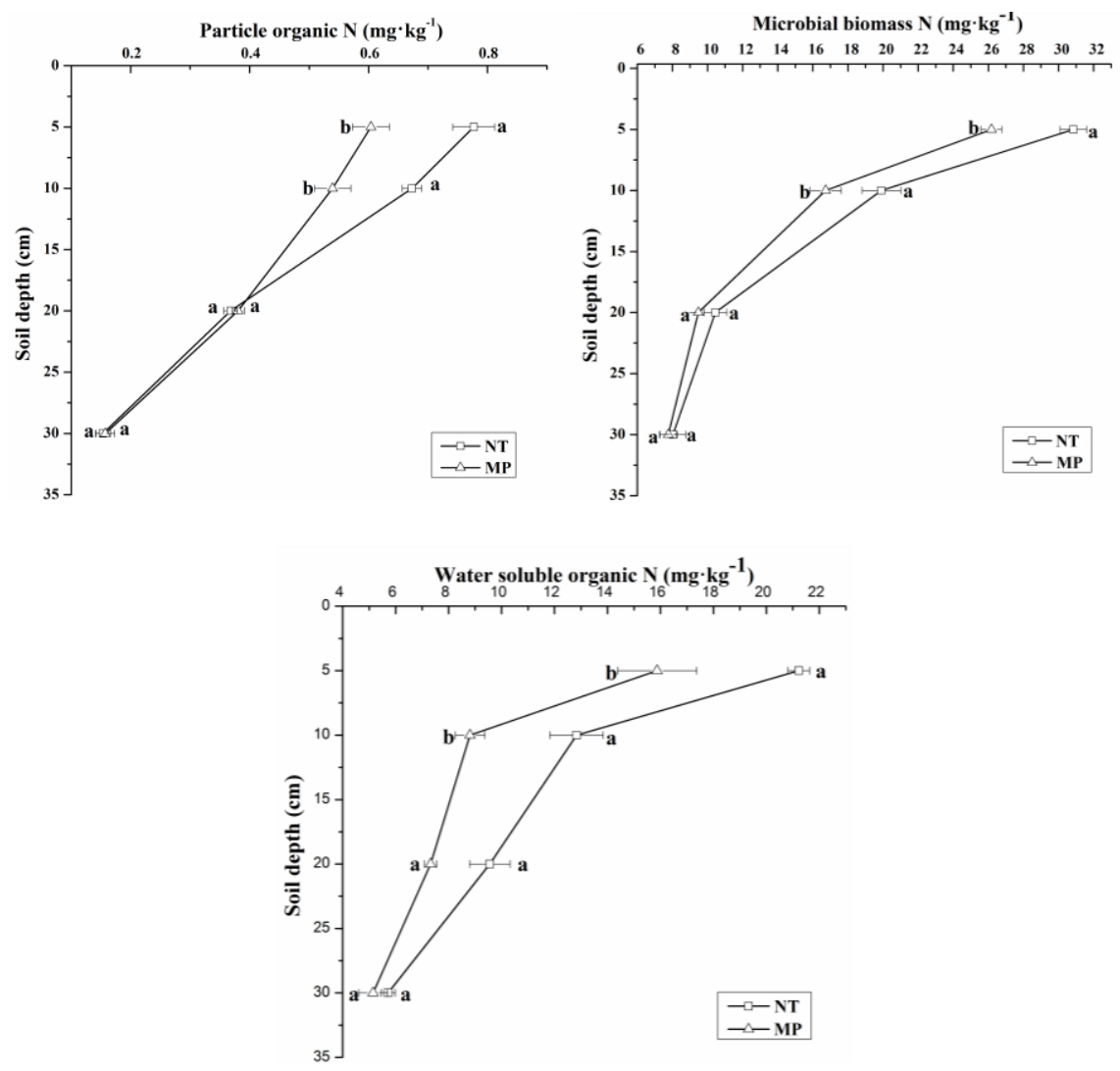

Figure 2. Depth distributions of particulate organic $N$, microbial biomass $N$ and water soluble organic $N$ under different tillage practices $(P<0.05)$. (NT: no tillage; MP: mould plow.

Different letter indicates significant difference of particulate organic $N$, microbial biomass $N$ and soluble water soluble organic $N$ between different tillage practices at the same depth)

\section{Soil inorganic nitrogen}

The $\mathrm{NO}_{3}{ }^{-} \mathrm{N}$ content in the $0-5 \mathrm{~cm}$ and $5-10 \mathrm{~cm}$ soil layers under NT were $28.10 \%$ and $32.13 \%$, significantly ( $\mathrm{p}<0.05)$ higher than that of MP, respectively (Fig. 3).
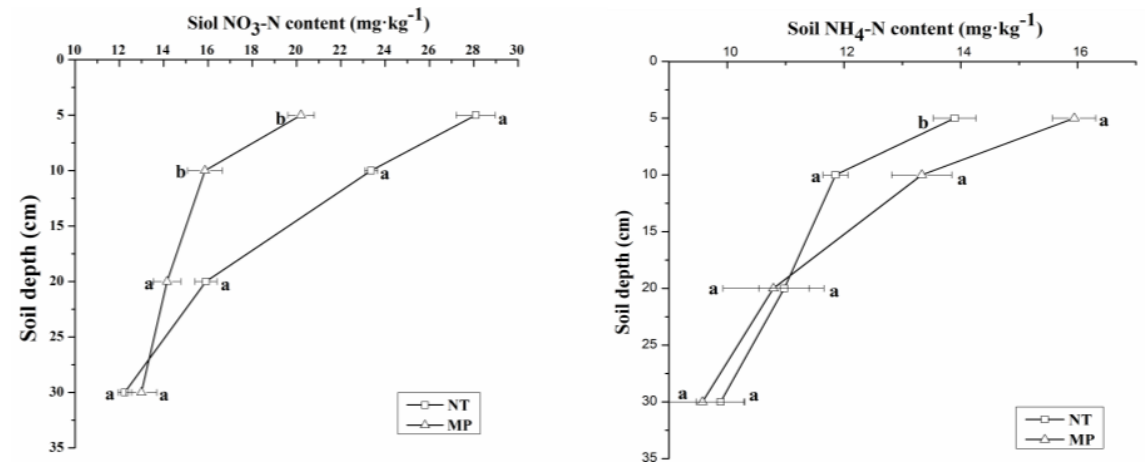

Figure 3. Depth distributions of soil $\mathrm{NO}_{3}{ }_{3} \mathrm{~N}$ and $\mathrm{NH}_{4}{ }^{-} \mathrm{N}$ under different tillage practices $(P<0.05)$. (NT: no tillage; MP: mould plow. Different letter indicates significant difference of soil $\mathrm{NO}_{3}-\mathrm{N}$ and $\mathrm{NH}_{4}-\mathrm{N}$ between different tillage practices at the same depth) 
The $\mathrm{NH}_{4}{ }^{-} \mathrm{N}$ content in the $0-5 \mathrm{~cm}$ soil layer under MP was $12.86 \%$ significantly ( $\mathrm{p}<0.05$ ) higher than that of $\mathrm{NT}$, the $\mathrm{NH}_{4}{ }^{-} \mathrm{N}$ content under MP in the $5-10 \mathrm{~cm}$ soil layer was also higher than NT although the difference was not significant. There was no significant difference between NT and MP for $\mathrm{NO}_{3}-\mathrm{N}$ and $\mathrm{NH} 4-\mathrm{N}$ in the $10-30 \mathrm{~cm}$ soil layer. With the increment of soil depth, the content of nitrate nitrogen and ammonium nitrogen decreased.

\section{Soil organic nitrogen components}

NT significantly $(\mathrm{p}<0.05)$ increased total hydrolysable nitrogen content, hydrolysable ammonia nitrogen content, and hydrolysable amino acid nitrogen in topsoil (0-5 and 5-10 cm) more than MP (Table 2). Compared with MP, total hydrolysable nitrogen content increased by $22.03 \%$, and $9.67 \%$, hydrolysable ammonia nitrogen increased by $22.24 \%$ and $19.67 \%$, and hydrolysable amino acid nitrogen increased by $21.48 \%$ and $22.95 \%$ in the $0-5 \mathrm{~cm}$ and $5-10 \mathrm{~cm}$ soil layers, respectively (Table 2). No significant difference was observed in the 10-30 cm soil layers for the hydrolysable nitrogen. Tillage practices had no significant effect on the content of hydrolysable amino sugar nitrogen. The content of hydrolysable amino sugar nitrogen in the 10-30 $\mathrm{cm}$ soil layer was slightly lower than MP, but the difference was not significant. The hydrolysable unidentified nitrogen content in the $0-5 \mathrm{~cm}$ soil layer of the NT treatment was $30.87 \%$ significantly ( $\mathrm{p}<0.05$ ) higher than that in MP, while the differences between the two nitrogen types for NT and MP in the 5-30 cm depth interval were not significant. The differences of all types of nitrogen between NT and MP in the $10-30 \mathrm{~cm}$ soil layer were not significant.

Table 2. Soil organic nitrogen components under different tillage practices

\begin{tabular}{c|c|c|c|c|c}
\hline Soil depth $(\mathbf{c m})$ & & $\mathbf{0 - 5}$ & $\mathbf{5 - 1 0}$ & $\mathbf{1 0 - 2 0}$ & $\mathbf{2 0 - 3 0}$ \\
\hline \multirow{2}{*}{ Total hydrolysable nitrogen } & NT & $1438.76 \mathrm{a}$ & $1249.49 \mathrm{a}$ & $957.18 \mathrm{a}$ & $812.79 \mathrm{a}$ \\
& MP & $1121.87 \mathrm{~b}$ & $1038.37 \mathrm{~b}$ & $1015.78 \mathrm{a}$ & $839.70 \mathrm{a}$ \\
\multirow{2}{*}{ Hydrolysable ammonia nitrogen } & NT & $587.23 \mathrm{a}$ & $510.45 \mathrm{a}$ & $412.49 \mathrm{a}$ & $348.84 \mathrm{a}$ \\
& MP & $484.31 \mathrm{~b}$ & $410.01 \mathrm{~b}$ & $437.46 \mathrm{a}$ & $357.63 \mathrm{a}$ \\
Hydrolysable amino sugar nitrogen & NT & $44.21 \mathrm{a}$ & $35.54 \mathrm{a}$ & $29.82 \mathrm{a}$ & $24.29 \mathrm{a}$ \\
& MP & $34.13 \mathrm{a}$ & $31.72 \mathrm{a}$ & $31.68 \mathrm{a}$ & $24.87 \mathrm{a}$ \\
Hydrolysable amino acid nitrogen & NT & $482.82 \mathrm{a}$ & $450.74 \mathrm{a}$ & $294.44 \mathrm{a}$ & $250.21 \mathrm{a}$ \\
& MP & $379.11 \mathrm{~b}$ & $347.28 \mathrm{~b}$ & $344.20 \mathrm{a}$ & $281.50 \mathrm{a}$ \\
Hydrolysable unidentified nitrogen & NT & $324.51 \mathrm{a}$ & $252.76 \mathrm{a}$ & $220.42 \mathrm{a}$ & $189.46 \mathrm{a}$ \\
& MP & $224.32 \mathrm{~b}$ & $249.36 \mathrm{a}$ & $202.44 \mathrm{a}$ & $175.70 \mathrm{a}$ \\
\hline
\end{tabular}

Same letter means no significant difference under different layers and tillage practices for a single soil nitrogen property. NT: no tillage; MP: mould plow

\section{Discussion}

\section{Effect of tillage on soil total nitrogen content}

After 16 years of conversion from traditional farming to conservation tillage, the TN content in the $0-10 \mathrm{~cm}$ surface layer increased under no-till practices. Our results were consistent with other research, such as that no-tillage had shown that total nitrogen at 0$5 \mathrm{~cm}$ and 0-30 $\mathrm{cm}$ layers was higher than that for other tillage (Power et al., 1998; 
Purakayastha et al., 2009). As a result of the NT straw surface coverage, soil disturbance decreased, leading to a reduction of total nitrogen mineralization and eventually an increase in total nitrogen (Franzluebbers et al., 1999). No-tillage straw also increased the soil $\mathrm{C} / \mathrm{N}$ ratio by adding organic matter to the soil, thus enhancing the solid holding capacity of nitrogen (Kushwaha et al. al., 2000; Hemwong et al., 2008; Zavalloni et al., 2011). The total nitrogen content both in NT and MP decreased with increases in soil depth. This was due to the accumulation of organic matter in the surface NT soil. In the $10-30 \mathrm{~cm}$ soil layer, total nitrogen content under MP treatment was higher than NT (Fig. 1). For this phenomenon, underground biomass may play an important role. In traditional farming, the stubble was turned into the deeper layer of soil. However, in NT, the root system showed a high density in the soil surface and a low density in the deep soil (Qin et al., 2006). Therefore, different subsurface biomass in NT and MP may cause the difference of total nitrogen in various soil layers between treatments. The results of the present study are consistent with other findings; no-tillage straw returning to the soil led to accumulation of soil nitrogen on the soil surface (Torbert et al., 1995; Thomas et al., 2005).

\section{Effect of tillage on soil active nitrogen}

Soil particulate organic nitrogen (PON) was considered as a stable part of soil organic nitrogen, as it could be converted into inorganic nitrogen, which could then be used to supply nitrogen sources for plant growth and crop yield, and maintain soil nitrogen balance (Rosell et al., 2000). PON was sensitive to farmland management practices such as soil disturbance and crop straw inputs; therefore, it responded quickly to management practice changes (Cambardella et al., 1992). These results showed that conservation tillage mainly increased the PON content in the $0-5 \mathrm{~cm}$ and $5-10 \mathrm{~cm}$ soil layers, which is consistent with other related studies (Fabrizzi et al., 2003; Bessam et al., 2003; Malhi et al., 2006; Sainju et al., 2012). There are three reasons for this. First, no-till straw returning could provide a good environment for soil aggregate formation, and a large amount of PON could be physically protected in soil aggregates. Second, cultivation such as autumn plowing could disturb the soil and destroy soil aggregates, thus accelerating PON mineralization (Wander, 2004). Third, the location of crop straw returning may affect the distribution of PON. In the NT treatment, the straw covered the soil surface. However, in the MP treatment, straws were buried in the soil stubble in more close contact with the soil. The variable distribution of straw returning to the field could explain that the PON content in NT treatment was significantly higher than MP in the $0-10 \mathrm{~cm}$ soil layer. To summarize, the results showed that no-tillage straw returned to the soil helps increase soil PON content.

Soil microbial biomass nitrogen was the source and reservoir of nitrogen nutrients and an important biological indicator of soil quality (Shukla et al., 2017). In the present study, conservation tillage significantly increases soil microbial biomass nitrogen. This may be due to the higher total nitrogen content in conservation tillage soils, which provided a higher material basis for MBN formation. The positive impact of NT on soil microbial communities could also be attributed to the reduction of soil disturbance, which led to the reduction of fungal mycelium damage, the conservation of microbial habitat, the improvement of soil moisture conditions and the reduction of extreme temperature conditions (Rhoton, 2000). In short, NT increased soil microbial and physic-chemical conditions, improved microbial habitat, disturbed soil less, and 
provided relatively high levels of organic nitrogen, ultimately resulting in an increase in surface microbial biomass nitrogen.

Soil soluble organic nitrogen played an important role in the farmland nitrogen circulation system (Kranabetter et al., 2007). In this study, no-tillage straw surface coverage resulted in an increase in soil soluble organic nitrogen in the $0-10 \mathrm{~cm}$ soil layer. The disturbance of mould plow tillage soils improved the aeration of the soil and destroyed the soil aggregates, thus accelerating the mineralization of PON. Therefore, the soil soluble organic nitrogen tended to decrease, resulting in the decrease in the surface layer content. Meanwhile, no-tillage straw covering the surface could improve soil moisture and boost nitrogen fixation.

\section{Effect of tillage on soil inorganic nitrogen}

Soil inorganic nitrogen played an important role in the forms of nitrate nitrogen and ammonium nitrogen in the soil nitrogen cycle, and was the main form of crop absorption and utilization, although only a minor portion of the total nitrogen (Nguyen et al., 2017). Halvorson found that the $\mathrm{NO}_{3}-\mathrm{N}$ content in mould plow tillage in the northern plains of the United States was higher than that of no-tillage systems (Halvorson et al., 2000). In this study $\mathrm{NO}_{3}-\mathrm{N}$ content in $0-10 \mathrm{~cm}$ soil under NT layer was significantly higher than that of MP, which is not consistent with this finding. which may be related to different crop types, tillage years, soil types and planting systems. Our results showed that no-tillage with straw returned to the soil would increase the number and continuity of macropores in the topsoil and may cause a large amount of $\mathrm{NO}_{3}-\mathrm{N}$ to be stored in the surface soil ( $\mathrm{Li}$ et al., 2007). At the same time, notillage could effectively store soil moisture and reduce $\mathrm{NO}_{3}-\mathrm{N}$ leaching to the lower soil. In addition, the straw covered the surface of no-tillage soil, which increased soil nitrogen fixation, thereby reducing the loss of $\mathrm{NO}_{3}-\mathrm{N}$. In contrast, conventional farming led to large disturbances of surface soil with high porosity with $\mathrm{NO}_{3}-\mathrm{N}$ tending to move downwards. Sainju et al. (2013) found that the $\mathrm{NH}_{4}-\mathrm{N}$ content in MP was higher than in NT, which is consistent with our findings. Under dry land conditions, Li et al. (2007) found that no-tillage increased the quantity of earthworms in farmland and the number and continuity of macropores in the soil, thus improving soil aeration. In well-aerated soil, $\mathrm{NH}_{4}-\mathrm{N}$ was more easily transferred into $\mathrm{NO}_{3}-\mathrm{N}$, resulting in soil $\mathrm{NH}_{4}-\mathrm{N}$ content decreasing under no-tillage.

\section{Effect of tillage on soil organic activated nitrogen components}

Soil organic nitrogen is the source of mineral nitrogen for crops, and as the main form of soil nitrogen, it plays a key role in the stability of farmland ecosystems (Schulten et al., 1997). In this study, no-tillage significantly affected the total hydrolysable nitrogen, hydrolysable ammonia nitrogen and hydrolysable amino acid nitrogen in the $0-10 \mathrm{~cm}$ soil layer, and hydrolysable unidentified nitrogen in the $0-5 \mathrm{~cm}$ soil layer. The reason may be that no-tillage increased the total nitrogen content of soil, and the increase in total nitrogen would inevitably lead to the increase in soil hydrolysable ammonia nitrogen (Follett et al., 1989). Hydrolysable ammonia nitrogen was composed of inorganic exchangeable ammonium and part of the fixed ammonium composition, the mineralization of two ammonium after soil disturbance accelerated under conventional farming, and the absorption and utilization of crops to ammonia, led to the average content of hydrolysable ammonia nitrogen decreasing obviously; hence, 
hydrolysable ammonia nitrogen in the $0-10 \mathrm{~cm}$ layer of mould plow tillage was significantly lower than no-tillage (Jiang, 2005). The addition of organic material under no-tillage increased the soil organic matter content, which was continuously converted into humus under the action of microorganisms. Soil amino acids nitrogen and other compounds of $\mathrm{N}$ were fixed into humic acid during the humification (Porter et al., 1964). Under acidic conditions, the amino acid nitrogen released, which made the higher hydrolysable amino acid nitrogen content of the $0-10 \mathrm{~cm}$ soil layer than that of conventional tillage. Hydrolysable unidentified nitrogen is a difficult component to mineralization in soil organic nitrogen pools of acidolysis, and the mineralization rate of unknown nitrogen of acidolysis is very small, so it is easy to accumulate in soil (Stevenson, 1982). The increase in total nitrogen in the surface layer under no-tillage also leads to the increase in hydrolysable unidentified nitrogen. Tillage practices have no significant effect on hydrolysable amino sugar nitrogen. Since hydrolysable amino sugar nitrogen is mainly derived from residues of microbial cell walls, and hydrolysable amino sugar nitrogen reflects the accumulation of dead microorganisms rather than live microorganisms. Therefore, hydrolysable amino sugar nitrogen is a very small percentage of soil total nitrogen, and it is less affected by tillage practices (Stevenson, 1982). Liu's preliminary studies conducted in the same site reported that the soil organic nitrogen mineralization plays an important role in the nitrogen nutrition of crops. The total soil nitrogen mineralization rate in no-tillage has a significant stratification phenomenon. The contribution of no-till active organic nitrogen to total mineralization rate (75-89\%) was significantly greater than that of conventional tillage $(31-45 \%)$, indicating that tillage practices will affect the source of soil organic nitrogen mineralization. The degree of humification, humic acid content, and aromaticity of organic matter in long-term no-tillage mollisol were significantly lower than that of mould plow tillage, so the mineralization of active organic nitrogen pool contributed more to the total primary mineralization rate. This means that much more organic nitrogen in no-till agecan be converted into inorganic nitrogen and absorbed by plants (Liu et al., 2017).

\section{Conclusion}

The results of this study showed that the effects of conservation tillage on the soil nitrogen pool occurred in the surface layer by significantly increasing the contents of total nitrogen, particulate nitrogen, microbial biomass nitrogen, water-soluble organic nitrogen, nitrate nitrogen and acidolysis of organic nitrogen components. In sum, notillage was suitable to increase the accumulation of nitrogen in dry farming areas, which would provide a theoretical basis for optimizing mollisol management and sustainable development of agriculture with rational fertilizing in Northeast China.

Acknowledgements. This research was supported by the National Natural Science Foundation of China (41430857), Key Research Program of Frontier Sciences, Chinese Academy of Sciences (Grant No. QYZDB-SSW-DQC035), Youth Innovation Promotion Association, Chinese Academy of Sciences (2015183), National Key R\&D Program of China (2017YFC0504200), “135" project planning of Northeast Institute of Geography and Agroecology, Chinese Academy of Sciences (Y6H2042001), Open Research Funds from the Key Laboratory of Mollisols Agroecology, Chinese Academy of Sciences (2016ZKHT-02). 


\section{REFERENCES}

[1] Ballb, C., Scott, A., Parker, J. P. (1999): Field $\mathrm{N}_{2} \mathrm{O}, \mathrm{CO}_{2}$ and $\mathrm{CH}_{4}$ fluxes in relation to tillage compaction and soil quality in Scotland. - Soil \& Tillage Research 53: 29-39.

[2] Barajas-Guzmán, M. G., Campo, J., Barradas, V. L. (2006): Soil water, nutrient availability and sapling survival under organic and polyethylene mulch in a seasonally dry tropical forest. - Plant and Soil 287(1-2): 347-357.

[3] Bessam, F., Mrabet, R. (2003): Long-term effect of tillage and cropping systems on particulate organic matter of a Calcixeroll soil of semi-arid Morocco. - Proceedings 16th Triennial Conference of International Soil Tillage Research Organization, Brisbane, Australia, 13-18 July, pp. 144-149.

[4] Bremner, J. M., Edwards, A. P. (1965): Determination and isotope-ratio analysis of different forms of nitrogen in soils: I. Apparatus and procedure for distillation and determination of ammonium. - Soil Science Society of America Journal 29(5): 504-507.

[5] Cambardella, C. A., Elliott, E. T. (1992): Particulate soil organic-matter changes across a grassland cultivation sequence. - Soil Science Society of America Journal 56(3): 777783.

[6] Chen, X. W., Chang, L., Liang, A. Z., Wu, D. H., Zhang, X. P. Yang, J. M. (2018): Effects of long term conservation tillage on soil nitrogen content and organic nitrogen components in a Chinese Mollisol. - Applied Ecology and Environmental Research 16(1): 663-675.

[7] Dikgwatlhe, S. B., Chen, Z. D., Lal, R. (2014): Changes in soil organic carbon and nitrogen as affected by tillage and residue management under wheat-maize cropping system in the North China Plain. - Soil and Tillage Research 144: 110-118.

[8] Fabrizzi, K. P., Moron, A., García, F. O. (2003): Soil carbon and nitrogen organic fractions in degraded vs. non-degraded Mollisols in Argentina. - Soil Science Society of America Journal 67(6): 1831-1841.

[9] Follett, R., Schimel, D. S. (1989): Effect of tillage practices on microbial dynamics. Soil Soc Am J 53: 1091-1096.

[10] Franzluebbers, A. J., Langdale, G. W., Schomberg, H. H. (1999): Soil carbon, nitrogen, and aggregation in response to type and frequency of tillage. - Soil Science Society of America Journal 63(2): 349-355.

[11] Fuzzi, S. (1996): Overview of the biogenic sources of atmospheric trace compounds due to agricultural activities. - Aerobiologia 12: 129-132.

[12] Gao, Y. H., Luo, P., Wu, N. (2008): Impacts of grazing intensity on nitrogen pools and nitrogen cycle in an alpine meadow on the eastern Tibetan plateau. - Applied Ecology and Environmental Research 3(6): 69-79.

[13] Gigliotti, G., Kaiser, K., Guggenberger, G. (2002): Differences in the chemical composition of dissolved organic matter from waste material of different sources. Biology and Fertility of Soils 36(5): 321-329.

[14] Halvorson, A. D., Black, A. L., Krupinsky, J. M., Merrill, S. D., Wienhold, B. J., Tanaka, D. L.(2000): Spring wheat response to tillage and nitrogen fertilization in rotation with sunflower and winter wheat. - Agronomy Journal 92(1): 136-144.

[15] Haynes, R. J. (2005): Labile organic matter fractions as central components of the quality of agricultural soils: an overview. - Advances in Agronomy 85(4): 221-268.

[16] Hemwong, S., Cadisch, G., Toomsan, B. (2008): Dynamics of residue decomposition and $\mathrm{N}_{2}$ fixation of grain legumes upon sugarcane residue retention as an alternative to burning. - Soil and Tillage Research 99(1): 84-97.

[17] Jiang, X. D., Li, Z. J., Hou, L. T. (2005): Impacts of minimum tillage and no-tillage systems on soil $\mathrm{NO}_{3}-\mathrm{N}$ content and water use efficiency of winter wheat summer corn cultivation. - Transactions of the CSAE 21(7): 20-24.

[18] Jiang, X. F. (2005): The effect on soil organic nitrogen under the different tillage in dryland. - Doctoral dissertation, Gansu Agricultural University. 
[19] Jones, D. L., Shannon, D., Murphy, D. V., Farrar, J. (2004): Role of dissolved organic nitrogen (DON) in soil N cycling in grassland soils. - Soil Biology \& Biochemistry 36: 749-756.

[20] Ju, X. T., Liu, X. J., Zhang, F. S. (2004): Effects of long-term fertilization on soil organic nitrogen fractions. - Scientia Agricultura Sinica 37(1): 87-91.

[21] Karra, R., Maslouhi, A., Bamba, Y. O. (2018): Modeling of nitrogen transport in variably saturated soils. - Applied Ecology and Environmental Research 2(6): 1427-1444.

[22] Kranabetter, J. M., Dawson, C. R., Dunn, D. E. (2007): Indices of dissolved organic nitrogen, ammonium and nitrate across productivity gradient of boreal forests. - Soil Biology Biochemistry 39(12): 3147-3158.

[23] Kushwaha, C. P., Tripathi, S. K., Singh, K. P. (2000): Variations in soil microbial biomass and $\mathrm{N}$ availability due to residue and tillage management in a dryland rice agroecosystem. - Soil and Tillage Research 56(3): 153-166.

[24] Lenssen, A. W., Waddell, J. T., Johnson, G. D. (2007): Diversified cropping systems in semiarid Montana: Nitrogen use during drought. - Soil and Tillage Research 94(2): 362375.

[25] Li, H., Gao, H., Wu, H., Li, W. Y., W, X. Y., H, J. (2007): Effects of 15 years of conservation tillage on soil structure and productivity of wheat cultivation in northern China. - Soil Research 45(5): 344-350.

[26] Liu, S. Y., Zhang, X. P., Zhao, J. (2017): Effects of long-term no tillage treatment on gross soil $\mathrm{N}$ transformations in black soil in Northeast China. - Geoderma 301: 42-46.

[27] Lou, Y., Xu, M., Chen, X. (2012): Stratification of soil organic C, N and C: N ratio as affected by conservation tillage in two maize fields of China. - Catena 95: 124-130.

[28] Malhi, S. S., Lemke, R., Wang, Z. H. (2006): Tillage, nitrogen and crop residue effects on crop yield, nutrient uptake, soil quality, and greenhouse gas emissions. - Soil and Tillage Research 90(1): 171-183.

[29] Matthews, A. M., Armstrong, A. C. (2000): Development and testing of a model for predicting tillage effects on nitrate leaching from cracked clay soils. - Soil and Tillage Research 53(3): 245-254.

[30] Mkhabela, M. S., Madani, A. Gordon, R. (2008): Gaseous and leaching nitrogen losses from no-tillage and conventional tillage systems following surface application of cattle manure. - Soil and Tillage Research 98(2): 187-199.

[31] Nguyen, T. T. N., Xu, C. Y., Tahmasbian, I., Che, R. W., Xu, Z. H., Zhou, X. H., Wallacea, H. M., Bai, S. H. (2017): Effects of biochar on soil available inorganic nitrogen: A review and meta-analysis. - Geoderma 288: 79-96.

[32] Patra, D. D., Ram, M., Singh, D. V. (1993): Influence of straw mulching on fertilizer nitrogen use efficiency, moisture conservation and herb and essential oil yield in Japanese mint (Mentha arvensis L.). - Fertilizer Research 34(2): 135-139.

[33] Porter, L. K., Stewart, B., A., Haas, H., J. (1964): Effect of long-term cropping on hydrolysable organic nitrogen fraction in some Great Plant soils. - Soil Sci. Soc. Am. Proc 28: 368-370.

[34] Power, J. F., Peterson, G. A. (1998): Nitrogen transformations, utilization, and conservation as affected by fallow tillage method. - Soil and Tillage Research 49(1): 3747.

[35] Purakayastha, T. J., Smith, J. L., Huggins, D. R. (2009): Microbial biomass and N cycling under native prairie, conservation reserve and no-tillage in Palouse soils. - Geoderma 152(3): 283-289.

[36] Qin, R., Stamp, P., Richner, W. (2006): Impact of tillage on maize rooting in a Cambisol and Luvisol in Switzerland. - Soil and Tillage Research 85(1): 50-61.

[37] Ram, M., Ram, D. Roy, S. K. (2003): Influence of anorganic mulching on fertilizer nitrogen use efficiency and herb and essential oil yields in geranium Pelargonium graveolens. - Bioresource Technology 87(3): 273-278. 
[38] Rhoton, F. E. (2000): Influence of time on soil response to no-till practices. - Soil Science Society of America Journal 64(2): 700-709.

[39] Rosell, R. A., Galantini, J. A., Suner, L. G. (2000): Long-term crop rotation effect on organic carbon, nitrogen, and phosphoru: Haplustoll soil fraction. - Arid Soil Research and Rehabilitation 14(14): 309-315.

[40] Sainju, U. M., Caesar-Tonthat, T., Lenssen, A. W., Evans, R. G., Kolberg, R. (2009): Tillage and cropping sequence impacts on nitrogen cycling in dryland farming in eastern Montana, USA. - Soil and Tillage Research 103(2): 332-341.

[41] Sainju, U. M., Lenssen, A. W., Caesartonthat, T. (2012): Dryland soil nitrogen cycling influenced by tillage, crop rotation, and cultural practice. - Nutrient Cycling in Agroecosystems 93(3): 309-322.

[42] Sainju, U. M., Stevens, W. B., Evans, R. G., Iversen, W. M. (2013): Irrigation system and tillage effects on soil carbon and nitrogen fractions. - Soil Science Society of America Journal 77: 1225-1234.

[43] Schulten, H. R., Schnitzer, M. (1997): The chemistry of soil organic nitrogen: a review. Biology \& Fertility of Soils 26(1): 1-15.

[44] Shukla, S. K., Yadav, R. L., Awasthi, S. K., Gaur, A. (2016): Soil Microbial Biomass Nitrogen, In Situ Respiration and Crop Yield Influenced by Deep Tillage, Moisture Regimes and N Nutrition in Sugarcane-Based System in Subtropical India. - Sugar Tech 19(2): 1-11.

[45] Stevenson, F. J. (1982): Organic forms of soil nitrogen. - Nitrogen in Agricultural Soils: 67-122.

[46] Sun, L., Chang, S. X., Feng, Y. S., Dyck, M. F., Puurveen, D. (2015) : Nitrogen fertilization and tillage reversal affected water-extractable organic carbon and nitrogen differentially in a Black Chernozem and a Gray Luvisol. - Soil Tillage Res 146: 253-260.

[47] Thomas, G. A., Dalal, R. C., Standley, J. (2007): No-till effects on organic matter, p H, cation exchange capacity and nutrient distribution in a Luvisol in the semi-arid subtropics. - Soil and Tillage Research 94: 295-304.

[48] Torbert, H. A., Reeves, D, W. (1995): Interactions of traffic and tillage applied to cotton on $\mathrm{N}$ movement below the root zone of a subsequent wheat crop. - Soil and Tillage Research 33: 3-16.

[49] Vance, E. D., Brookes, P. C., Jenkinson, D. S. (1987): An extraction method for measuring soil microbial biomass C. - Soil biology and Biochemistry 19(6): 703-707.

[50] Varvel, G. E., Wilhelm, W. W. (2011): No-tillage increases soil profile carbon and nitrogen under long-term rainfed cropping systems. - Soil and Tillage Research 114(1): 28-36.

[51] Wander, M., Magdoff, F., Ray, R. W. (2004): Soil Organic Matter Fractions and Their Relevance to Soil Function. - In: Magdoff, F., and Weil, R. R. (eds.) Soil Organic Matter in Sustainable Agriculture. CRC Press, Boca Raton, FL.

[52] Xu, Y. C., Shen, Q. R. Ran, W. (2003): Content and distribution of forms of organic N in soil and particle size fractions after long-term fertilization. - Chemosphere 50(6): 739745 .

[53] Zavalloni, C., Alberti, G., Biasiol, S. (2011): Microbial mineralization of biochar and wheat straw mixture in soil: A short-term study. - Applied Soil Ecology 50: 45-51. 